\title{
ELECTRICALLY CONDUCTIVE FIBERS IN CLUSTER BOMBLETS WHICH TARGETED THE ELECTRIC POWER SYSTEM OF FR YUGOSLAVIA IN 1999
}

\author{
Mirjana N. Anđelković-Lukića ${ }^{a}$ Mirjana D. Stojanovićb \\ ${ }^{a}$ Military Technical Institute, Belgrade, Republic of Serbia; \\ Government of the Republic of Serbia, Interagency Coordination \\ Body, Belgrade, Republic of Serbia, \\ e-mail: mirjana.andjelkovic.lukic45@gmail.com, corresponding author, \\ ORCIDiD: (1)https://orcid.org/0000-0002-5076-4901 \\ ${ }^{b}$ Institute for Technology of Nuclear and Other Mineral Raw Materials, \\ Belgrade, Republic of Serbia, \\ e-mail: mira1412@gmail.com, \\ ORCIDiD: (1)https://orcid.org/0000-0003-4509-391X
}

DOI: 10.5937/vojtehg68-27231; https://doi.org/10.5937/vojtehg68-27231

FIELD: Chemical technology

ARTICLE TYPE: Original scientific paper

Abstract:

Introduction/purpose: The paper presents the mode of operation of the CBU-102(V) 2/B cluster bomb, weighing about $340 \mathrm{~kg}$ and containing bomblets with electrically conductive fibers for disabling power plants.

Methods: Physical and chemical analyses of the fibers were performed. The following test methods were used for fiber characterization: a binocular microscope for determining fiber thickness and a qualitative XRF analysis performed on an XRF-MiniPal spectrometer, PANalytical. The $X R F a n a l y s i s$ aimed at qualitative detection of the present elements, which was confirmed by a quantitative chemical analysis.

Results: The semi-quantitative XRF analysis determined the content of gallium (0.007\%), the peak of which was detected on the spectrum. Gallium nitride is a material that can be used as a semiconductor. The chemical analysis was performed on an atomic absorption spectrophotometer Analyst 300, Perkin Elmer.

Conclusion: The instrument for differential thermal analysis and thermogravimetry (DTAVTG), NETZCH STA 409 EP (operational range from $20^{\circ} \mathrm{C}$ to $1000^{\circ} \mathrm{C}$ ), confirmed that the sample was of $50 \%$ silicate origin, non-toxic and with heavy metal content in traces. The rest of the 
sample is aluminum whose presence in soil can cause decline in soil fertility thus leading to decline in crop yields.

Keywords: chemical warfare, cluster bomb, electrically conductive fibers, energy system, chemical analysis, thermochemical analysis, silicate, aluminum, environmental impact, soil, declined fertility, reduced yield.

\section{Introduction}

The attack on FR Yugoslavia began with a combined action of tomahawk cruise missiles (BGM-109 TLM) and AGM-86-ALCM launched from V-52N strategic bombers, which took off from RAF Fairford base (Great Britain) and from the southern Adriatic sea from submarines and ships of the Sixth fleet, USA Navy. A total of 78 projectiles were launched in the first raid. At the same time, about 300 planes took off from the aircraft carriers from the Sixth fleet and bases in Italy, Germany and Turkey, 100-200 out of which were fighters, armed with the most modern guided munitions (air bombs and air-to-ground and air-to-air missiles). They deployed air attacks with the aim of destroying and neutralizing vital facilities of the Yugoslav Army, and especially the Air Force (RV) and the Air Defense (PVO), with a quick operation. After the war, the Pentagon publicly stated that the focus of the operation was the destruction and neutralization of the air defense system of FR Yugoslavia (AnđelkovićLukić, 2015, p.36).

Military doctrines in the world's largest countries hold the view that war conflicts, such as those in Iraq, Bosnia and Herzegovina, Chechnya and Yugoslavia, can be successfully resolved by selective attacks on vital enemy targets using high-precision weapons from a distance. Such aggressions are carried out by mass attacks with cruise missiles and aviation on airports, positions of missile units and air defense radars, command posts, telecommunication systems, but also on the country's economic infrastructure in order to immediately overcome resistance and endanger the existence of the population. For this purpose, CBU-102/B cluster bombs with BLU-114/B bomblets were deployed against electric power facilities. At the same time, cluster bombs with high-explosive bomblets were used against civilian targets such as residential buildings, hospitals, schools, etc. (reference) All missiles dropped on FR Yugoslavia during the bombing, in terms of their effect and purpose, can be classified into three general groups:

- high-explosive (HE), guided and unguided, of various calibers, (missiles, air bombs and cluster bombs), 
- anti-tank, armour-piercing, filled with depleted uranium, and

- non-lethal, which do not have the effect of an explosion at the target, but cause serious damage, so-called "soft bombs" or "blackout bombs".

The paper will present the properties and action of bombs for incapacitation of electric power facilities and the physico-chemical analysis of electrically conductive fibers contained in cluster bomblets within cluster bombs and containers. (Anđelković-Lukić, 2015, p.36).

Electrically conductive fibers are intended to create blackouts, to disable the power grid of a state, leaving it without electricity. This includes hospitals, industrial plants, schools, colleges, etc.

They were first used over Iraq, but their chemical structure was that of graphite fibers, an allotropic modification of carbon, which is also highly conductive. Therefore, all such bombs containing electrically conductive fibers are popularly called graphite bombs, and, despite the difference in their composition, they all work in the same way: they disrupt the electricity supply in the attacked country. (Jeler \& Roman, 2016, pp.13-18)

The fibers dropped on FR Yugoslavia were the product of highly sophisticated technology, a product of the fourth generation, and they work by causing short circuits on transmission lines.

Cluster bombs with electrically conductive fibers targeting the electrical grid of FR Yugoslavia

Depending on the model, cluster bombs (CBUs - Cluster Bomb Units) consist of the body of the SUU-65/B or SUU-66/B (Stores Release and Suspension Unit) air bomb loaded with 202 BLU-114/B bomblets. The CBU-102/B cluster bomb weighs about $340 \mathrm{~kg}$ and bomblets, $1 \mathrm{~kg}$ each, are filled with spools of conductive filaments. It was developed for the US Air Force to be dropped from the altitudes of $600 \mathrm{~m}-6000 \mathrm{~m}$ at a speed of 460 up to $1.200 \mathrm{~km} / \mathrm{h}$. It is released from aircraft and covers an elliptical surface measuring approximately $150 \times 360 \mathrm{~m}$. This bomb was developed in 1994, and became operational in the US Armed Forces in the late 1990s. (Anđelković-Lukić, 2015, pp.57-58)

Bombs with electro-conductive fibers (which contains BLU-114/B bomblets, produced in the USA) were used in the NATO aggression on FR Yugoslavia (1999), when more than $70 \%$ of the electricity in the national power grid was disabled. 
In less than 24 hours, experts from Serbia managed to restore the operability of the electrical system, so that the used bombs with electrically conductive fibers did not give the expected results. (Jeler \& Roman, 2016, pp.15)

In the territory of FR Yugoslavia (Republic of Serbia), the power transmission system in 1999 consisted of:

1) Overhead lines (transmission lines) a total of 449 in the length of $9,408 \mathrm{~km}$, by voltage levels:

- $400 \mathrm{kV}-37$, in the length of $1,626 \mathrm{~km}$;

- $220 \mathrm{kV}-48$, in the length of $1,917 \mathrm{~km}$;

$-110 \mathrm{kV}-358$, in the length of $5,804 \mathrm{~km}$;

- $35 \mathrm{kV}-6$, in the length of $141 \mathrm{~km}$;

2) Underground lines (cables) of voltage level $110 \mathrm{kV}, 2$ in total, in the length of $6.1 \mathrm{~km}$;

3) Transformer stations (TS) a total of 30 , total installed capacity 15.396 MVA, by voltage levels:

- 400/H kV/kV - 14, total installed capacity 9,750 MVA;

- 220/H kV/kV - 13, total installed capacity 5,343 MVA;

- 110/H kV/kV - 3, total installed capacity 303.5 MVA and

4) Distribution plants (DP) a total of 8 , by voltage levels, as follows:

$-400 \mathrm{kV}-4$

$-220 \mathrm{kV}-1$,

- 110 kV - 4. (Energy Agency of the Republic of Serbia, 2017, p.8)

Cluster bombs targeted overhead lines, transformer stations and switchyards.

The electric power system of the FR of Yugoslavia was targeted with cluster air bombs with BLU-114/B bomblets from the beginning to the end of May 1999:

- May 2, 1999, at $9.45 \mathrm{pm}$, the substations TS 400/200 kV "Obrenovac", TS 220/35 kV "Bajina Bašta", TS 2400/220/110kV "Niš", TS 400/220/110kV "Novi Sad" and distribution plant RP 400kV "Drmno".

- May 7, 1999, at $9.21 \mathrm{pm}$, the substations TS 400/220 kV "Belgrade 8", TS 220/110 kV "Belgrade 5", TS 400/220 kV "Obrenovac" and TS 220/110 "Belgrade 3". 
- May 13, at $10.40 \mathrm{pm}$, distribution plants RP $400 \mathrm{kV}$ "Drmno" and RP 10/35 kV TPP "Kolubara" and the substations TS 400/220/110 kV "Niš 2", TS 400 and 110 kV "Novi Sad 3".

- May 22, at 2.18 p.m, the substations TS 400/220 kV "Drmno", TS 400/220 kV "Belgrade 8", TS 400/220/110 kV "Niš 2", TS 220/35 kV "Bajina Bašta" and the plant 110 kV TPP "Kostolac A". (Dveri srpske, pp.68-69)

Due to a small mass of fibers, winds occasionally carried conductive fibers from uncleaned parts of facilities and their surrounding areas, which then fell on the already cleaned parts of the electrical system and short circuits and power outages occurred repeatedly.

Engineers from the Military Technical Institute with colleagues from the Faculty of Technology and Metallurgy in Belgrade successfully solved the lifting of conductive fibers from the ground, using a certain procedure, by which thin threads were glued to the ground and there was no possibility for their re-lifting.

Their lifting into the air and causing short circuits again was thus prevented. When the enemy realized that Serbian electric power grid workers were successfully repairing the damage from conductive fibers and that there was practically no damage to the electric power system, they started firing $\mathrm{HE}$ bombs at transformer stations. This resulted in subsequent soil contamination, because transformer oil leaked from the hit transformer stations and went into the water and into the soil (Anđelković-Lukić, 2015, p.104).

\section{How the CBU-102/B cluster bomb works}

The CBU-102/B cluster bomb has a timer fuze with an altimeter which at a given height from the ground activates a detonation blade that cuts off the front and the rear of the bomb with the stabilizer, and the container is cut along its length to three parts at an angle of $120^{\circ}$ (Figure 1 ) thus releasing cluster bomblets under the action of air current and centrifugal force. Spools are made of silicon fiber covered with a molecular layer of aluminum probably applied by a special process, evaporation under vacuum, or by a nanotechnological process. (Anđelković-Lukić, 2015, p.55) 


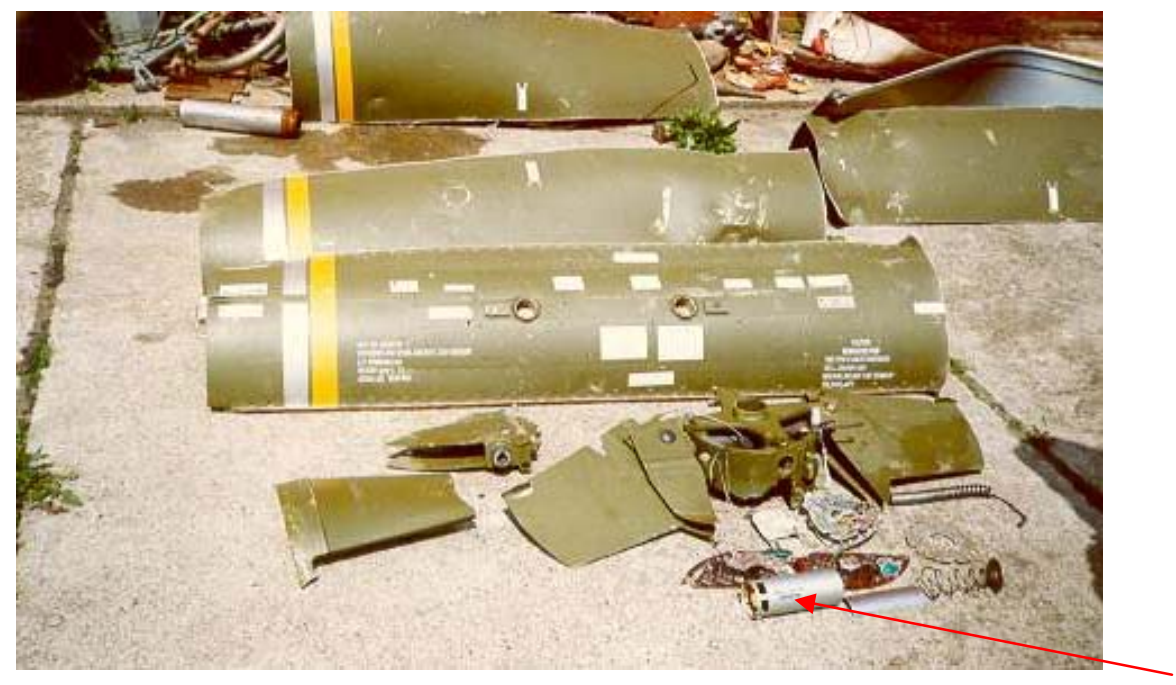

Figure 1 - Parts of an activated CBU-102/B cluster bomb (in Figures 1 and 2, inactivated BLU-114/B bomblets are marked with the arrows) (Serbian Armed Forces, 1999)

Puc. 1 - Части активированной кассетной бомбы CBU-102/B (на рисунках 1 и 2 стрелками отмечены неактивированные бомбы BLU-114/B) (Serbian Armed Forces, 1999)

Слика 1 - Делови активиране касетне бомбе CBU-102/B (на сликама 1 и 2 стрелицама су обележене неактивиране бомбице BLU-114/B) (Serbian Armed Forces, 1999)

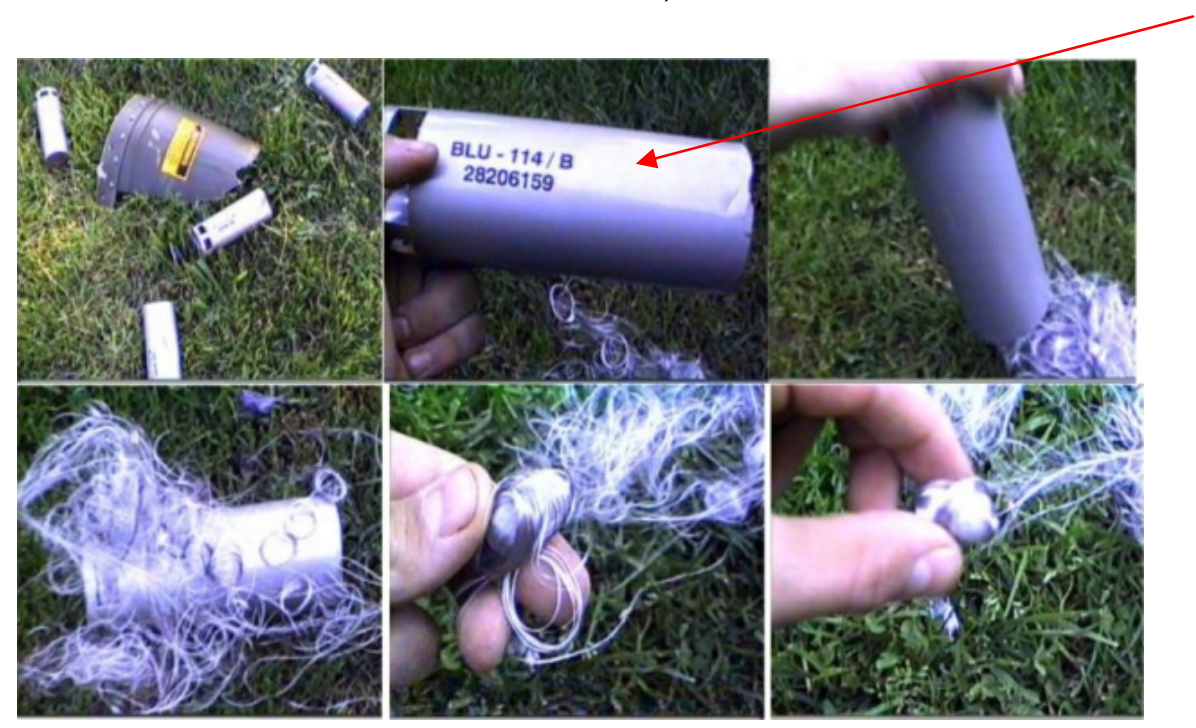

Figure 2 - Content of the BLU-114/B cluster bomblet (Serbian Armed Forces, 1999) Puc. 2 - Содержание кассетной бомбы BLU-114/B (Serbian Armed Forces, 1999) Слика 2 - Садржај касетне бомбице BLU-114/B (Serbian Armed Forces, 1999) 
Table 1 shows the technical characteristics of the CBU-102/B cluster bomb, and Figure 3 shows the arrangement of spools in the cluster bomblet shell, top view.

Table 1 - Technical characteristics of the CBU-102/B cluster air bomb

Таблица 1 - Технические характеристики кассетной авиационой бомбы CBU102/B

Табела 1 - Техничке карактеристике касетне авио-бомбе CBU-102/B

\begin{tabular}{|l|l|}
\hline Purpose and the name & $\begin{array}{l}\text { CBU-102/B cluster air bomb for disabling } \\
\text { electric power facilities }\end{array}$ \\
\hline Total weight & $340 \mathrm{~kg}$ \\
\hline Charge & $\begin{array}{l}\text { BLU-114/B bomblets }(202 \text { pieces, } \\
\text { individual weight of about } 1 \mathrm{~kg})\end{array}$ \\
\hline Dimensions of the BLU-114/B bomblet & Length $16.7 \mathrm{~cm}$, diameter $6.7 \mathrm{~cm}$ \\
\hline Number of spools & 147 pieces \\
\hline Weight of a spool & $2 \mathrm{~g}$ \\
\hline Length of a filament in a spool & $150 \mathrm{~m}$ \\
\hline Material & Glass fibers with aluminum coating \\
\hline Manufacturer & USA \\
\hline
\end{tabular}

CBU-102/B cluster bombs are carried by F-117 aircraft and manufactured in the USA (Jeler \& Roman, 2016, pp.13-18).

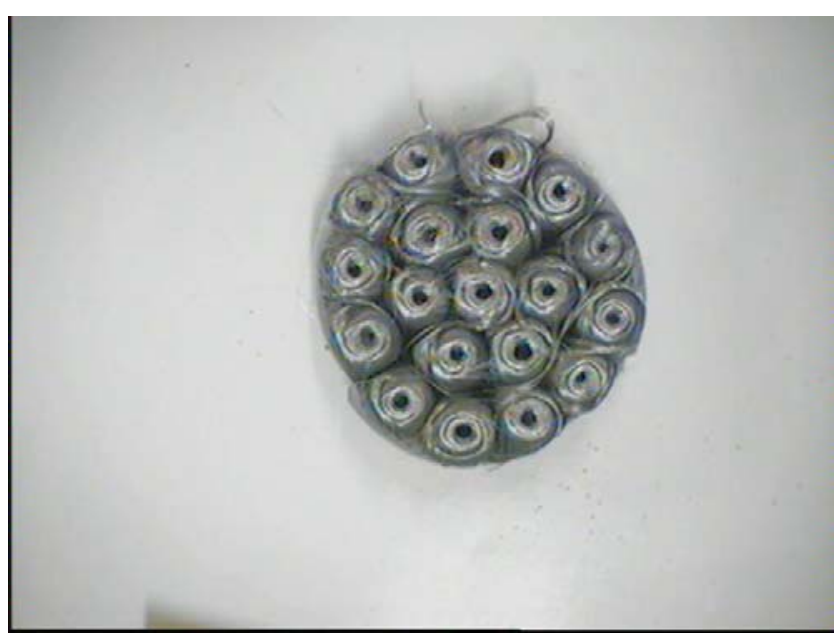

Figure 3 - Arrangement of spools in the bomblet, top view (Serbian Armed Forces, 1999) Puc. 3 - Расположение катушек в бомбе малого калибра, вид сверху (Serbian Armed Forces, 1999)

Слика 3 - Распоред калемова у бомбици, изглед са горње стране (Serbian Armed Forces, 1999) 
Figure 4 shows an open bomblet and a mechanism for opening the shell.

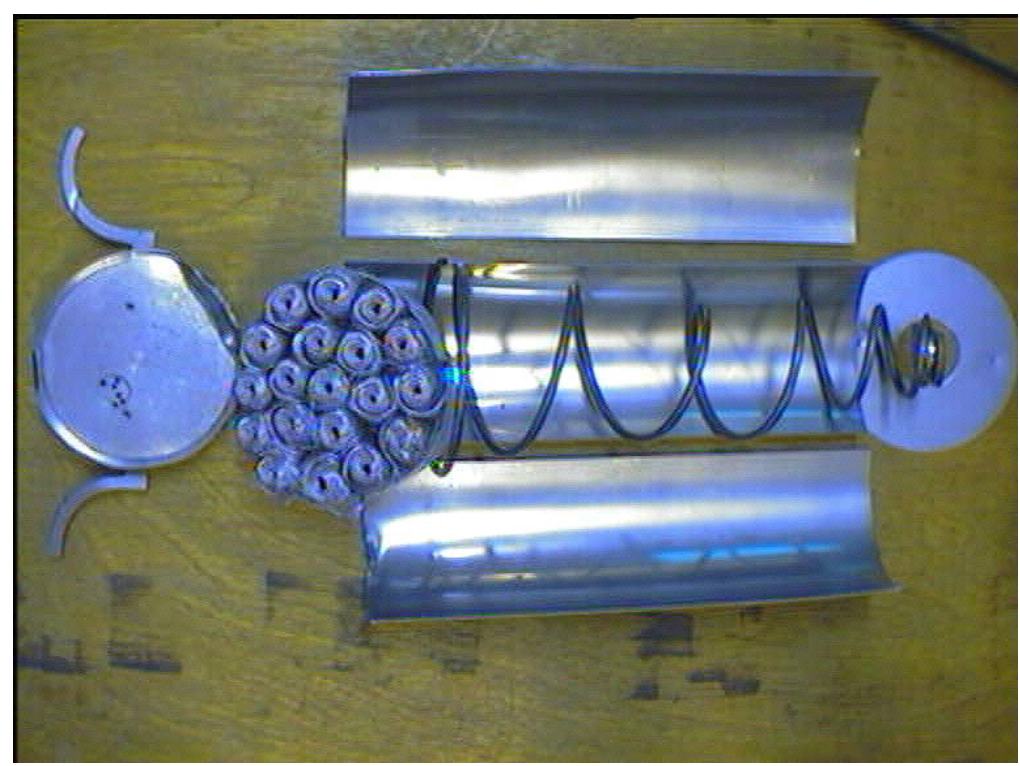

Figure 4 - Parts of an open cluster bomblet with spools and an ejection mechanism (Serbian Armed Forces, 1999)

Puc. 4 - Части открытой кассеты с катушками и механизмом выбрасывания (Serbian Armed Forces, 1999)

Слика 4 - Делови отворене касетне бомбице са калемовима и избацним механизмом (Serbian Armed Forces, 1999)

After being dispersed from bomblets, spools unwind and conductive filaments fall on high-voltage lines of the power system and form electrically conductive lines which cause short circuits and electrical discharges. Unwound filaments have a length of about $150 \mathrm{~m}$, and while they fall, they unwind into a number of thinner ones creating a net at the point of impact, covering large areas. Such a net has higher strength than individual filaments. Figure 5 shows unwound electrically conductive filaments on transmission lines.

A short circuit is accompanied by filament evaporation, ionization of the air and the formation of an intensive current flow between the wires of the transmission line, i.e. the appearance of electric arcs, with accompanying manifestations: temperatures above $4000^{\circ} \mathrm{C}$ and strong flashes of whitish light. Not only does the power system break down, but 
also high temperatures can cause fires and explosions. (AnđelkovićLukić, 2015, p.58).

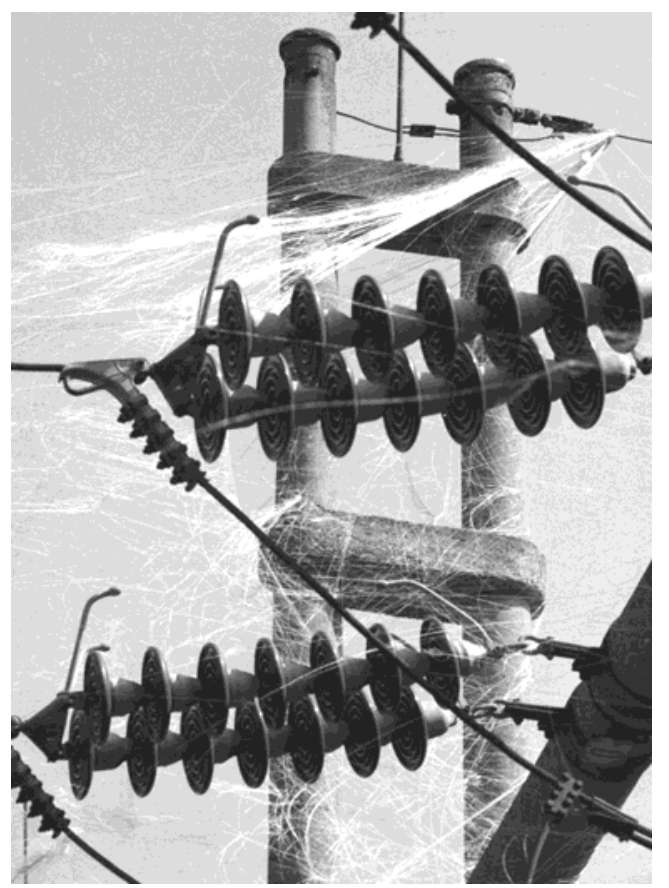

Figure 5 - Electrically conductive filaments on power transmission lines (Serbian Armed Forces, 1999)

Puc. 5 - Электропроводящие волокна на линиях электропередачи (Serbian Armed Forces, 1999)

Слика 5 - Електропроводљива влакна на далеководима (Serbian Armed Forces, 1999)

\section{Characterization of electrically conductive fibers}

In order to characterize electrically conductive fibers, a qualitative XRF analysis, a (DTA/TG) analysis and a chemical quantitative analysis were performed. The analyses were performed at the Institute for Technology of Nuclear and Other Mineral Resources in Belgrade and represent the first test for the Commission for Investigating the Consequences of NATO Bombing in 1999, formed by a Government decision in June 2018.

The analysis sample was taken from one spool from an inactivated BLU-114/B cluster bomblet. Figure 6 shows a spool sample for a fiber analysis. 


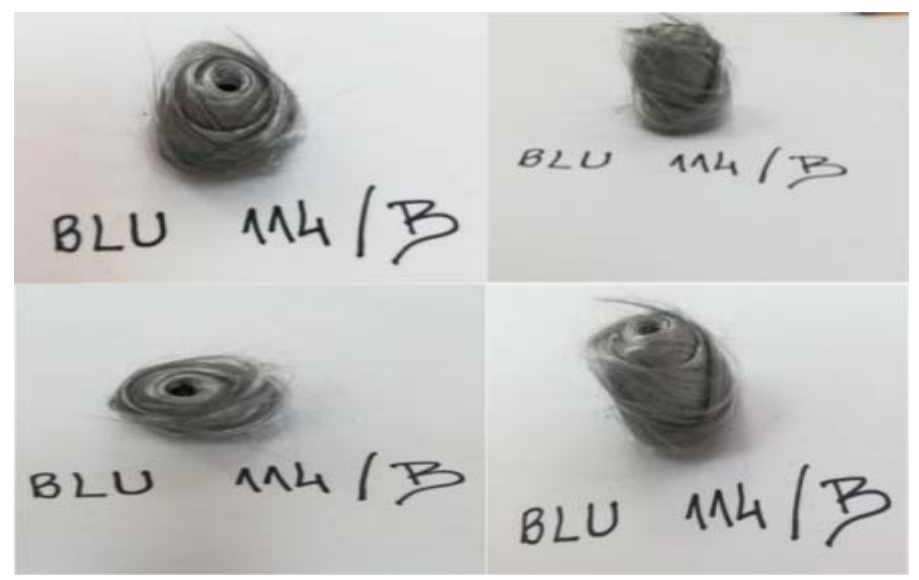

Figure 6 - Samples for the analysis - a separate spool of fibers from a cluster bomblet (Serbian Armed Forces, 1999)

Puc. 6 - Образцы для анализа - извлеченная из кассетной бомбы волоконная катушка (Serbian Armed Forces, 1999)

Слика 6 - Узорци за анализу - издвојен намотај влакана из касетне бомбице (Serbian Armed Forces, 1999)

Figure 7 shows a BLU-114/B fiber magnified on a binocular microscope.

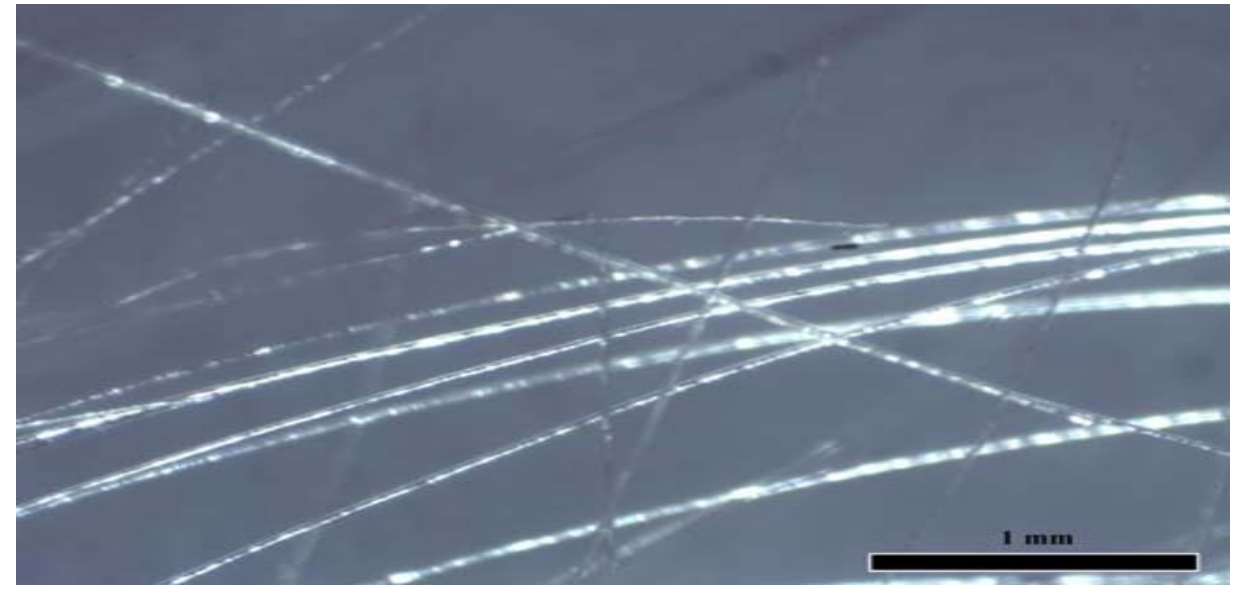

Figure 7 - External appearance of a conductive fiber from the BLU-114/B, magnified on a binocular microscope (size - $1 \mathrm{~mm}$ ) (Serbian Armed Forces, 1999)

Puc. 7 - Вид проводящего волокна из BLU-114/B, увеличенный под бинокулярным микроскопом (размер - 1 мм) (Serbian Armed Forces, 1999)

Слика 7 - Спољни изглед проводљивог влакна из BLU-114/B, увећан на бинокуларном микроскопу (размера : 1 mm) (Serbian Armed Forces, 1999)

\section{3}


The qualitative XRF analysis was performed on the XRF-MiniPal, PANalytical spectrometer, and the XRF spectrum of the fibers is shown in Figure 8 (the energy in $\mathrm{KeV}$ is represented on the $\mathrm{x}$-axis, and the relative intensity of the peak on the $y$-axis).

The spectrum was recorded using a sodium filter that reduces the intensity of interfering lines and background noise. The XRF analysis aimed at qualitative detection of the present elements, which was confirmed by a quantitative chemical analysis. The semi-quantitative XRF analysis determined the content of gallium $(0.007 \%)$, the peak of which was detected on the spectrum. Gallium nitride is a material that can be used as a semiconductor.

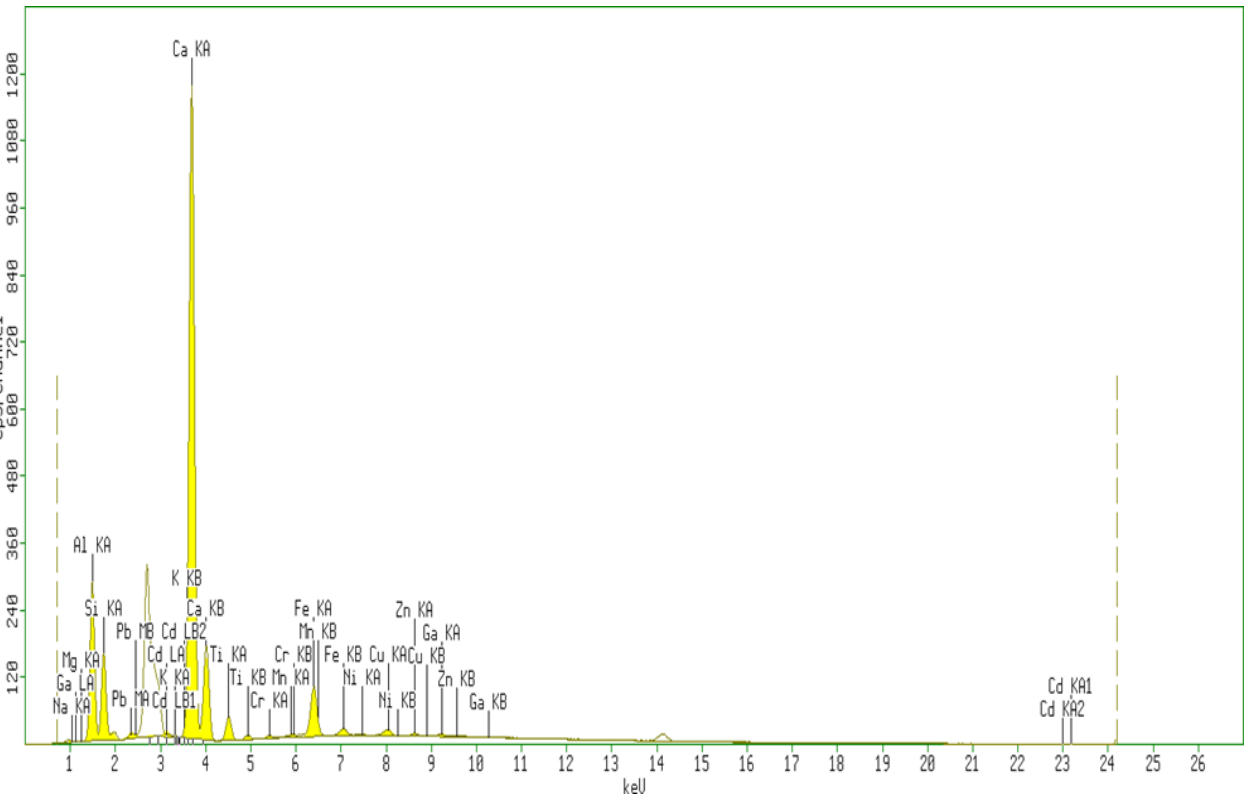

Figure 8 - XRF spectrum of a conductive fiber (with a sodium filter)

Puс. 8 - Рентгенофрлуоресцентный спектр провода (с натриевым фрильтром) Слика 8 - XRF спектар проводљивог влакна (са натријумским фрилтером)

The chemical analysis was performed on the atomic absorption spectrophotometer Analyst 300, Perkin Elmer (Table 2). The sample was dissolved in $\mathrm{HCl}$ (1: 1) and the insoluble residue was alkaline. 
Table 2 - Chemical analysis of the sample of conductive fibers from the BLU-114/B bomblet

Таблица 2 - Химический анализ образца проводящих волокон из бомбы BLU-114/B Табела 2 - Хемијска анализа узорка проводљивих влакана из бомбице BLU-114/B

\begin{tabular}{|c|l|l|l|l|l|l|l|l|}
\hline Element & $\mathrm{Al}$ & $\mathrm{SiO}_{2}$ & $\mathrm{CaO}$ & $\mathrm{MgO}$ & $\mathrm{Fe}_{2} \mathrm{O}_{3}$ & $\mathrm{Na}_{2} \mathrm{O}$ & $\mathrm{K}_{2} \mathrm{O}$ & $\mathrm{TiO}_{2}$ \\
\hline$\%$ & 51.400 & 31.640 & 13.260 & 1.606 & 0.495 & 1.132 & 0.104 & 0.329 \\
\hline Element & $\mathrm{Pb}$ & $\mathrm{Zn}$ & $\mathrm{Cu}$ & $\mathrm{Cd}$ & $\mathrm{Cr}$ & $\mathrm{Ga}$ & $\mathrm{Ni}$ & $\mathrm{MnO}$ \\
\hline$\%$ & 0.029 & 0.015 & 0.006 & $<0.001$ & 0.002 & 0.007 & $<0.001$ & 0.003 \\
\hline
\end{tabular}

Based on the chemical analysis of the conductive fibers, it is concluded that these are glass fibers coated with aluminum, which is in accordance with the literature data. Fang et al. (2010), write about the usage of ordnance with conductive fibers/filaments which can consist of carbon filaments or glass filaments with metal coating.

Filaments have a characteristic of creating a compulsively sequential arc that leads to a short circuit in the contact between two electrical phases or the phase and the ground.

The sum of all determined inorganic oxides that are part of the glass fiber is $48.5686 \%$, the content of heavy metals $(\mathrm{Pb}, \mathrm{Zn}, \mathrm{Cu}, \mathrm{Cd}, \mathrm{Ni})$ is $0.0522 \%$, the content of $\mathrm{Ga} 0.0074 \%$ and the content of aluminum is $51.400 \%$. The analysis of the acid-soluble part of the fiber detected all elements except $\mathrm{Si}$ which remained in the insoluble residue and after melting was transferred to the solution. This information is important from the point of view of the solubility of aluminum and its potential harmful effect on soil contamination and inclusion in the food chain.

The device for a thermal (DTA/TG) analysis is NETZCH STA 409 EP (operating range of $20-1000{ }^{\circ} \mathrm{C}$, with a heating rate of $\Delta T=10{ }^{\circ} \mathrm{C} / \mathrm{min}$ ). The experiments were performed in an air atmosphere. The differential thermal analysis, DTA, (Figure 9) indicates an endothermic peak at $659{ }^{\circ} \mathrm{C}$, which corresponds to the melting point of aluminum, which according to the literature is $660.3{ }^{\circ} \mathrm{C}$. The TGA, thermogravimetric analysis, indicates that there was no change in mass. The TGA of the sample resulted in melting of the metal without loss of mass. 


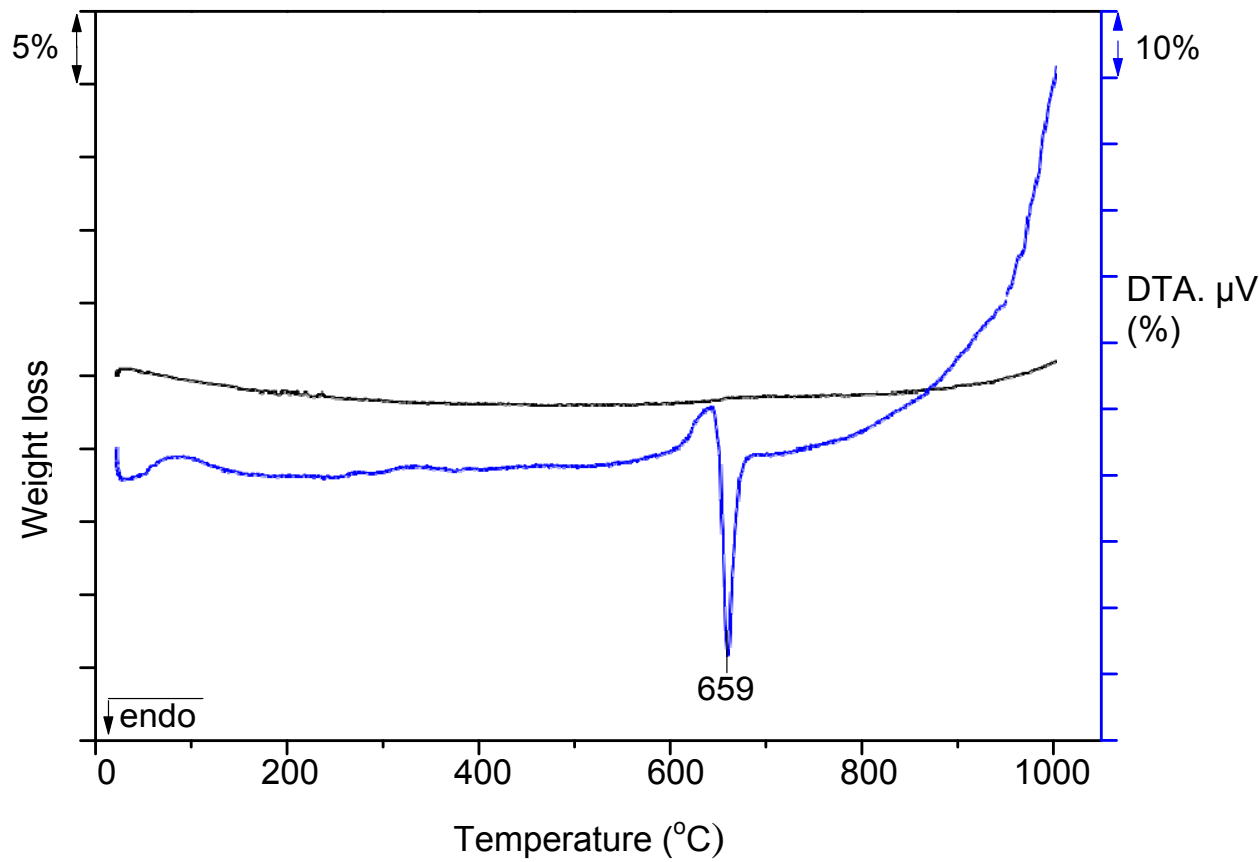

Figure 9 - Thermal analysis (DTA/TG) of a sample of conductive fibers Puc. 9 - Термический анализ (ДТАТГГ) образца проводящих волокон Слика 9 - Термијска анализа (DTA/TG) узорка проводљивих влакана

This is obviously a non-toxic sample that is about $50 \%$ of silicate origin.

\section{Ecological aspects of the impact of aluminum on} arable land

Aluminum makes up $51.40 \%$ of the fiber sample (Table 2). Its presence in the soil can cause the decline in soil fertility, which leads to the reduction in the yield of cultivated crops. The phyto-toxicity of aluminum in acidic soils has been the subject of numerous studies in the country and in the world. It is known that the harmful effects of aluminum depend on its concentration and form, the $\mathrm{pH}$ value, organic and inorganic ligands in the solution, the ionic strength, and the plant genotype. Aluminum binds strongly to phosphates, sulfates, and silicates, and its desorption from negatively charged soil colloids is difficult, given the highly positive charge (Mrvić et al, 2012, pp.257-262). 
Hydrogen and aluminum cations are responsible for soil acidity. Below $\mathrm{pH} 6$, the substitution acidity of the soil, aluminum is the main source of $\mathrm{H}+$ ions, due to the dissociation of Al from clay minerals. Aluminum becomes more soluble at lower $\mathrm{pH}$ values. Very acidic soils with the $\mathrm{pH}$ value below 4 are not suitable for agricultural production. Leachate from acid soils can contain substances, especially aluminum, which have a detrimental effect on the quality of surface water and groundwater and a negative effect on plants, animals, especially fish in watercourses and lakes. Research in recent decades indicates the harmful effect of $\mathrm{Al}$ on human health, with an emphasis on its role in Alzheimer's disease. (Rondeau et al, 2000, pp.59-66)

\section{Conclusion}

During the aggression on FR Yugoslavia in 1999, CBU-102/B cluster bombs with BLU-114/B bomblets filled with electrically conductive fibers were dropped on electric power facilities of FR Yugoslavia. Cluster bombs with high-explosive bomblets targeted civilian objects such as residential buildings, hospitals, schools, etc.

The qualitative XRF analysis of conductive fibers from BLU-114/B bomblets was performed on an XRF-MiniPal spectrometer, PANalytical. Spectrum recording was done using a sodium filter that reduces the intensity of interfering lines and background noise. The XRF analysis aimed at qualitative detection of the present elements, which was confirmed by a quantitative chemical analysis. The semi-quantitative XRF analysis determined the content of gallium $(0.007 \%)$, the peak of which was detected on the spectrum. Gallium nitride is a material that can be used as a semiconductor.

Based on the chemical analysis of the conductive fibers, it is concluded that they are glass fibers with aluminum coating, which is in accordance with the literature data (Fang et al, 2010).

The differential thermal analysis (DTA) indicates an endothermic peak at $659{ }^{\circ} \mathrm{C}$, which corresponds to the melting point of aluminum, which is, according to literature data, $660.3^{\circ} \mathrm{C}$.

It is obvious that this is a sample that is about $50 \%$ of silicate origin, non-toxic in nature, and with the content of heavy metals in traces, which is important from the point of view of environmental protection.

The rest of the sample consists of aluminum, the presence of which in the soil can cause the decline in soil fertility, resulting in a lower yield of cultivated crops. The phyto-toxicity of aluminum in acidic soils has been the subject of numerous studies in the country and in the world. 
Unfortunately, no study has been done after the aggression to determine the degree of degradation, i.e. decline in soil fertility due to residual electrically conductive fibers near the affected electric power facilities by analysing the content of accessible forms of aluminum, as forms that are easily adsorbed in plant organs and included in the food chain.

\section{References}

Anđelković-Lukić, M. 2015. Darovi milosrdnog anđela - Ekološko razmatranje rata NATO protiv SR Jugoslavije, 2. dopunjeno izdanje. Novi Sad: Balkanija (in Serbian). Serbian).

-Dveri srpske. 2009. Nato genocid. Dveri srpske, 10(41), pp.68-69 (in

-Energy Agency of the Republic of Serbia. 2017. Document number: 3123/2016-C-1, January 26, p.8. Belgrade: Energy Agency of the Republic of Serbia (in Serbian).

Fang, W., Shunshan, F., Wenxuan, W. \& Fuwang, L. 2010. Analysis of action mechanism of graphite bombs and reaction method of power system. In: International Conference on Power System Technology (POWERCON 2010), Zhejiang, China, pp.1-6, October 24-28. Available at: https://doi.org/10.1109/POWERCON.2010.5666135

Jeler, G.E. \& Roman, D. 2016. The Graphite Bomb: An Overview of its Basic Military Applications. Review of the Air Force Academy, 14(1), pp.13-18. Available at: https://doi.org/10.19062/1842-9238.2016.14.1.2.

Mrvić, V., Čakmak, D., Sikirić, B., Nikoloski, M., Delić, D., Belanović, S. \& Beloica, J. 2012. Effect of acidification on the content of water-soluble aluminium in pseudogleys. Ratarstvo i povrtarstvo, 49(3), pp.257-262 (in Serbian). Available at: https://doi.org/10.5937/ratpov49-2293.

Rondeau, V., Commenges, D., Jacqmin-Gadda, H. \& Dartigues, J-F. 2000. Relation between Aluminum Concentrations in Drinking Water and Alzheimer's Disease: An 8-year Follow-up Study. American Journal of Epidemiology, 152(1), pp.59-66. Available at: https://doi.org/10.1093/aje/152.1.59.

-Serbian Armed Forces (SAF). 1999. General Staff Archive. Belgrade: Serbian Armed Forces (SAF). 
ЭЛЕКТРОПРОВОДЯЩИЕ ВОЛОКНА В КАССЕТНЫХ БОМБАХ, СБРОШЕННЫХ НА ОБЪЕКТЫ ЭЛЕКТРОЭНЕРГЕТИЧЕСКОЙ СИСТЕМЫ СОЮЗНОЙ РЕСПУБЛИКИ ЮГОСЛАВИЯ В 1999 ГОДУ

Мирьяна Н. Анджелкович-Лукич ${ }^{\text {a }}$, корреспондент, Мирьяна Д. Стояновичб

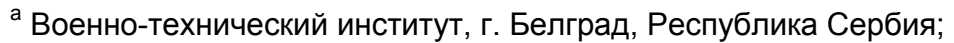

Правительство Республики Сербия, Межведомственный координационный орган, г. Белград, Республика Сербия

${ }^{\sigma}$ Институт технологий ядерных и других минеральных ресурсов,

г. Белград, Республика Сербия

РУБРИКА ГРНТИ: 78.00.00 ВОЕННОЕ ДЕЛО;

78.25.12 Химическое, биологическое и зажигательное оружие. Вооружения и средства радиационной, химической и биологической защиты,

61.00.00 ХИМИЧЕСКАЯ ТЕХНОЛОГИЯ. ХИМИЧЕСКАЯ ПРОМЫШЛЕННОСТЬ;

61.01.94 Охрана окружающей среды

ВИД СТАТЬИ: оригинальная научная статья

Резюме:

Введение/цель: В статье представлен способ фуннкционирования кассетной бомбы CBU-102(V) 2/B, массой около 340 ка, содержащей бомбы малого калибра $c$ электропроводящими волокнами, который был применен для выведения из строя электростанций.

Методы: В ходе исследования был выполнен фризический и химический анализ волокон. Для определения характеристик волокна использовались следующие методы: бинокулярный микроскоп для определения толщины волокна и качественный рентгенофрлуоресцентный анализ, выполненный на спектрометре XRF-MiniPal, PANalytical. Рентгенофлуоресцентный анализ был выполнен с целью качественного обнаружения присутствующих элементов, которое было подтверждено количественным химическим анализом.

Результаты: Полуколичественный рентгенофрлуоресцентный анализ выявил содержание галлия (0,007\%), пик которого был обнаружен на спектре. Нитрид галлия является материалом, который можно использовать в качестве полупроводника. Химический анализ проводили с помощью атомно-абсорбционного спектрофотометра Analyst 300, Perkin Elmer.

Выводы: Прибор для дифрференциального термического анализа и термогравиметрии (ДТА/TГ), NETZCH STA 409 EP (рабочий диапазон от $20^{\circ} \mathrm{C}$ до $\left.1000^{\circ} \mathrm{C}\right)$, подтвердил, что образеи 
содержал 50\% нетоксичного силиката и следы тяжелых металлов. Остальная часть образца содержала алюминий, присутствие которого в почве может вызвать снижение плодородия почвы, что как следствие приводит к снижению урожайности.

Ключевые слова: химическая война, кассетная бомба, электропроводящие волокна, энергетическая система, химический анализ, термохимический анализ, силикат, алюминий, воздействие на окружающую среду, почва, снижение плодородия, снижение урожайности.

\section{ЕЛЕКТРОПРОВОДЉИВА ВЛАКНА У КАСЕТИЦАМА БОМБИ КОЈИМА ЈЕ НАПАДНУТ ЕЛЕКТРОЕНЕРГЕТСКИ СИСТЕМ СР ЈУГОСЛАВИЈЕ 1999. ГОДИНЕ}

Мирјана Н. Анђелковић Лукић ${ }^{\text {, }}$, аутор за преписку, Мирјана Д. Стојановић ${ }^{6}$

а Војнотехнички институт, Београд, Република Србија;

Влада Републике Србије, Међуресорно координационо тело, Београд, Република Србија

${ }^{\sigma}$ Институт за технологију нуклеарних и других минералних сировина, Београд, Република Србија

ОБЛАСТ: хемијске технологије

ВРСТА ЧЛАНКА: оригинални научни рад

Сажетак:

Увод/циљ: У раду је приказан начин функционисања касетне бомбе CBU-102(V) 2/B, масе око $340 \mathrm{~kg}$, у којој се налазе бомбице са електропроводљивим влакнима којима су онеспособљавана електроенергетска постројења.

Meтоде: Извршене су фозичке и хемијске анализе влакна. За анализу влакана коришћене су следеће методе испитивања: бинокуларни микроскоп за одређивање дебљине влакна, квалитативна XRF анализа урађена на спектрометру XRF-MiniPal u PANalytical. Циљ XRF анализе био је да ce квалитативно детектују присутни елементи, што је потврђено и квантитативном хемијском анализом.

Резултати: Семиквантитативном XRF анализом одређен је садржај галијума (0,007\%), чији је пик детектован на спектру. Галијум-нитрид је материјал који се може користити као полупроводник. Хемијска анализа урађена је на атомскоабсорпционом спектрофотометру Analyst 300, Perkin Elmer.

Закључак: На уређају за диференцијално-термијску анализу и термогравиметрију (ДТАТТ), NETZCH STA 409 EP (опсег рада $\left.20-1000^{\circ} \mathrm{C}\right)$, потврђено је да се ради о узорку који је око 50\% 
силикатног порекла, нетоксичног карактера, са садржајем тешких метала у траговима. Остатак узорка чини алуминијум чије присуство у земљишту може да утиче на смањење плодности, што доводи до смањења приноса гајених култура.

Кључне речи: хемијски рат, касетна бомба, електропроводљива влакна, енергетски систем, хемијска анализа, термохемијска анализа, силикат, алуминијум, еколошки утицај, земљиште, смањење плодности, смањење приноса.

Paper received on / Дата получения работы / Датум пријема чланка: 24.06.2020. Manuscript corrections submitted on / Дата получения исправленной версии работы / Датум достављања исправки рукописа: 17.07.2020.

Paper accepted for publishingon / Дата окончательного согласования работы / Датум коначног прихватања чланка за објављивање: 18.07.2020.

(C) 2020 The Authors. Published by Vojnotehnički glasnik / Military Technical Courier (www.vtg.mod.gov.rs, втг.мо.упр.срб). This article is an open access article distributed under the terms and conditions of the Creative Commons Attribution license (http://creativecommons.org/licenses/by/3.0/rs/).

() 2020 Авторы. Опубликовано в «Военно-технический вестник / Vojnotehnički glasnik / Military Technical Courier» (www.vtg.mod.gov.rs, втг.мо.упр.срб). Данная статья в открытом доступе и распространяется в соответствии с лицензией «Creative Commons» (http://creativecommons.org/licenses/by/3.0/rs/).

(c) 2020 Аутори. Објавио Војнотехнички гласник / Vojnotehničkiglasnik / MilitaryTechnical Courier (www.vtg.mod.gov.rs, втг.мо.упр.срб). Ово је чланак отвореног приступа и дистрибуира се у складу са Creative Commons licencom (http://creativecommons.org/licenses/by/3.0/rs/).

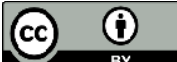

